\title{
STROŠEK IN UČINKOVITOST ZDRAVLJENJA SHIZOFRENIJE Z ATIPIČNIMI ANTIPSIHOTIKI V SLOVENIJI: RAZISKAVA STROŠKOVNE UČINKOVITOSTI THE COST AND EFFECTS OF ATYPICAL ANTIPSYCHOTIC AGENTS IN PATIENTS WITH SCHIZOPHRENIA IN SLOVENIA: A COST EFFECTIVENESS STUDY \\ Matej Štuhec ${ }^{1}$, Demetrij Petrica², Janez Toni
}

Prispelo: 15. 2. 2012 - Sprejeto: 2. 8. 2012

Izvirni znanstveni članek UDK 615.214:616.895.8

\section{Izvleček}

Uvod: Zdravljenje z atipičnimi antipsihotiki predstavlja najpomembnejši način zdravljenja bolnikov z akutno shizofrenijo in predstavlja veliki strošek. V Sloveniji nam primanjkuje raziskav stroškovne učinkovitosti atipičnih antipsihotikov, ki jih lahko uporabimo v klinični praksi.

Namen: Osnovni namen raziskave je bil primerjava stroškov in učinkovitosti petih atipičnih antipsihotikov z največjim tržnim deležem v letu 2011 v Sloveniji. V raziskavo smo vključili aripiprazol, kvetiapin, paliperidon, risperidon in olanzapin. Metode: Ciljna populacija v raziskavi so bili slovenski bolniki z akutno shizofrenijo. Vsak izmed petih antipsihotikov predstavlja glavno vejo odločitvenega drevesa. Terapevtska učinkovitost je bila določena kot verjetnost letne remisije. Ceno dnevnega zdravljenja s posameznim zdravilom smo pridobili iz podatkov tržnega deleža in prometa $v$ letu 2011, stroške mentalnega zdravstvenega varstva v Sloveniji pa smo pridobili iz podatkov Zavoda za zdravstveno zavarovanje Republike Slovenije. Raziskava je bila zasnovana z vidika plačnika, tj. Zavoda za zdravstveno zavarovanje Republike Slovenije.

Rezultati: Zdravljenje z risperidonom je najcenejše, najučinkovitejše pa z olanzapinom. Strategija zdravljenja z risperidonom ima najmanjši kvocient med stroški in učinkovitostjo. Strategije zdravljenja z aripiprazolom, s kvetiapinom in paliperidonom so prevladujoče. Cene letnega zdravljenja so: 6.812 EUR za risperidon, 7.509 EUR za kvetiapin, 7.295 EUR za olanzapin, 8.229 EUR za aripiprazol in 8.044 EUR za paliperidon. Učinkovitosti, podane $v$ deležu letne remisije, so: 0,605-kvetiapin, 0,603-aripiprazol, 0,671-risperidon, 0,723-olanzapin in 0,712-paliperidon. Sklep: Rezultati študije kažejo, da je najbolj stroškovno učinkovito zdravljenje akutne shizofrenije z risperidonom in olanzapinom.

Ključne besede: razmerje stroškovne učinkovitosti, odločitveno drevo, atipični antipsihotiki, klinični pomen

\section{Abstract}

Background: Treatment with atypical antipsychotics is the most important treatment for patients with acute schizophrenia and represents a significant cost. In Slovenia there is lack of studies of cost-effectiveness that can be used in clinical practice.

Objective: The primary purpose of the study was to compare the costs and effectiveness of five atypical antipsychotic with the largest market share in 2011 in Slovenia. The study included aripiprazole, quetiapine, paliperidone, risperidone and olanzapine.

Methods: The target population of the study were patients with acute schizophrenia in Slovenia. Each of the five antipsychotic drugs represents a major branch of the decision tree. Therapeutic effectiveness was defined as the percentage of patients in remission. The cost of daily treatment with each drug was obtained from the data traffic and market share in 2011, the costs of mental health care in Slovenia from the Health Insurance Institute of Slovenia. The study was conducted from the payer's perspective, the Health Insurance Institute of Slovenia. 
Results: Treatment with risperidone is the cheapest, while the most efficient is olanzapine. The strategy of treatment with risperidone has the smallest ration of cost-effectiveness. The strategy of treatment with aripiprazole, paliperidone and quetiapine are dominated. The price of treatment per year: $€ 6812$ for risperidone, $€ 7509$ for quetiapine, $€ 7295$ for olanzapine, $€ 8229$ for aripiprazole and $€ 8044$ for paliperidone. The efficiency given as a percentage of patients in remission are: 0.605 for quetiapine, 0.603 for aripiprazole, 0.671 for risperidone, 0.723 for olanzapine and 0.712 for paliperidone.

Conclusion: The data shows that the most cost-effective treatment of acute schizophrenia is with risperidone and olanzapine.

Key words: cost-effectiveness ratio, decision tree, atypical antipsychotics, clinical significance

\section{UVOD}

Shizofrenija je kronična duševna motnja, ki vključuje kronično ali ponavljajočo se psihozo (1). Povzroča veliko invalidnost in ekonomsko breme celotni svetovni populaciji. Po podatkih Svetovne zdravstvene organizacije sodi med deset najbolj obremenilnih bolezni sveta (2). Značilnosti shizofrenije običajno vključujejo pozitivne simptome, kot so: halucinacije in blodnje, neorganiziran govor, ter negativne simptome, kot so: nepovezan govor, čustvena, socialna otopelost in odmaknjenost. Diagnoza shizofrenije temelji na prisotnosti teh simptomov. Posameznik ima v življenju 0,2-0,7 \% možnosti, da zboli za shizofrenijo, svetovna letna incidenca je 11 ljudi na 100.000 prebivalcev (3, 4). Bolniki s shizofrenijo imajo višjo stopnjo umrljivosti kot splošna populacija ter višjo incidenco samomorov in nasilnih dejanj (5). Moški pogosteje obolevajo za shizofrenijo kot ženske (6).

Shizofrenijo zdravimo $v$ prvi vrsti $z$ antipsihotiki. Ti so učinkoviti pri zdravljenju simptomov shizofrenije pri približno $70 \%$ bolnikov (7). Obsežnih metaanaliz, ki bi vključevale primerjavo učinkovitosti posameznih antipsihotikov, z izjemo klozapina, nimamo na voljo. Posledično je edina pot primerjave učinkovitosti preko študij s placebom in med antipsihotiki (8). Zdravljenje z zdravili obsega akutno in vzdrževalno fazo.

Akutna faza se pojavi pri bolnikih s predhodno anamnezo shizofrenije, ki doživijo ponovni relaps ali prvič psihotični napad. Cilj zdravljenja v tej fazi je zmanjšanje jakosti psihotičnih misli in vedenja. Akutna faza traja od dva do šest tednov (9). V vzdrževalno fazo vstopimo, ko so psihotični simptomi razmeroma dobro nadzorovani. Cilj te faze je popolna vključitev posameznika $v$ družbo, zmanjšanje psihotične simptomatike ter preprečitev poslabšanja stanja in morebitnega relapsa bolezni. Bolnika zdravimo največkrat $z$ antipsihotikom, učinkovitim že v akutni fazi zdravljenja (10).

Zaradi velike prevalence in incidence duševnih motenj ter tako tudi shizofrenije v Sloveniji antipsihotiki vedno bolj bremenijo plačnike zdravstvenih storitev.
Podatki ambulantne porabe iz leta 2009 kažejo, da je 18 odstotkov vseh receptov obsegala $\mathrm{N}$ skupina po anatomski terapevtski klasifikaciji. Glede na leto 2008 je bilo v letu 2009 predpisanih za $3 \%$ več receptov z zdravili z delovanjem na živčevje, vrednost izdanih receptov pa se je povečala za $4 \%$. Največje stroškovno breme iz $\mathrm{N}$ skupine so antipsihotiki, katerih poraba iz leta $v$ leto raste, predvsem atipičnih antipsihotikov (11). V Sloveniji nimamo dovolj študij stroškovne učinkovitosti atipičnih antipsihotikov. Namen našega dela je ugotoviti stroškovno učinkovitost zdravljenja shizofrenije z atipičnimi antipsihotiki.

\section{METODE}

Raziskava stroškovne učinkovitosti (angl. Costeffectiveness analysis) temelji na odločitvenem drevesu, ki smo ga izdelali s pomočjo programa TreeAge $P R O \otimes$ 2012. Vključili smo pet glavnih vej, ki predstavljajo pet atipičnih antipsihotikov v peroralni obliki. Poimenovali smo jih po zdravilih: olanzapin, kvetiapin, risperidon, aripiprazol in paliperidon (Slika 1). Izbrali smo jih na osnovi tržnega deleža $v$ Sloveniji. $V$ raziskavo smo vključili atipične antipsihotike $z$ več kot $4 \%$ tržnim deležem v letu 2011 med atipičnimi antipsihotiki (12). Podatke o tržnem deležu antipsihotikov in cenah smo pridobili iz programa Pharmis $®$. Vnosni podatki $v$ odločitveno drevo so klinični in ekonomski. Skupaj določajo strošek določene poti zdravljenja, medtem ko klinični podatki določajo učinkovitost zdravljenja.

\subsection{Zasnova raziskave}

Odločitveno drevo raziskave temelji na odzivu bolnika na peroralno antipsihotično terapijo in izkušnjo z relapsom (Slika 1). Bolniki v akutnem stanju po diagnozi shizofrenije preidejo $v$ bolnišnici $v$ titracijsko fazo zdravljenja s peroralnim atipičnim antipsihotikom. Bolniki, ki se odzovejo na terapijo z zdravilom v šestih tednih, so odpuščeni iz bolnišnice in nadaljujejo zdravljenje do enega leta ambulantno. Predpostavili 
smo uspešno terapijo do enega leta, torej so tik pred enim letom v remisiji ali doživijo relaps s hospitalizacijo.
Bolniki, ki se ne odzovejo na zdravljenje po šestih tednih v bolnišnici, preidejo na drugi antipsihotik.

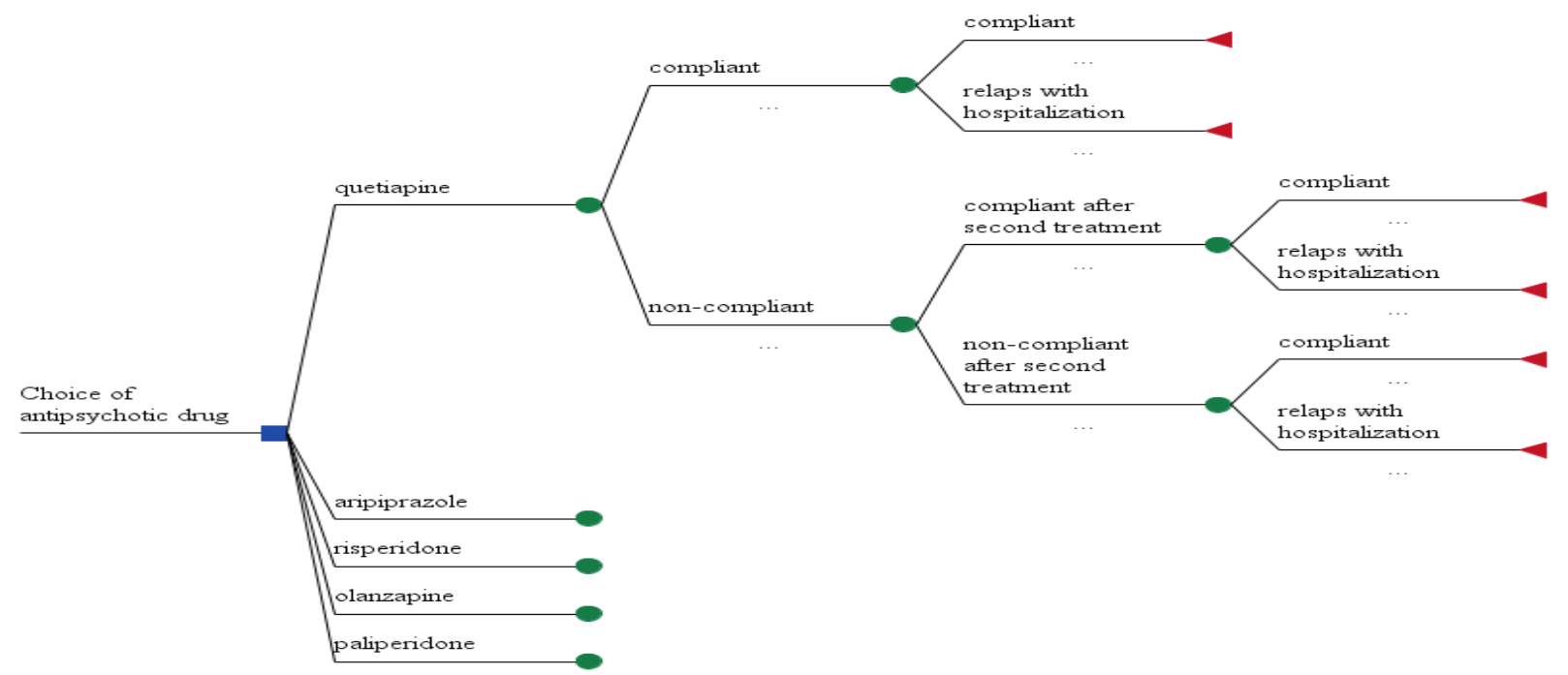

Slika 1. Odločitveno drevo za oceno ekonomskih podatkov pri atipičnih antipsihotikov za zdravljenje shizofrenije.

Figure 1. Decision tree for the economic evaluation of atypical antipsyhotics in the treatment of patients with shizophrenia.

Zdravljenje $z$ drugim antipsihotikom je lahko uspešno ali ne. V primerih odziva na zdravljenje $z$ drugim antipsihotikom so odpuščeni iz bolnišnice in nadaljujejo zdravljenje ambulantno. Sledi enaka pot kot v primeru uspešne terapije $v$ šestih tednih. Za bolnike, ki se tudi po menjavi antipsihotika ne odzovejo na zdravljenje, smo predpostavili $75 \%$ verjetnost relapsa $v$ enoletni raziskavi, kar so uporabili nekateri raziskovalci $v$ raziskavah stroškovne učinkovitosti (13).

Bolniki ob neuspešni terapiji prejmejo drugi antipsihotik iz raziskave, ki pa ni enak kot prvotni antipsihotik $v$ neuspešni terapiji. Klinična učinkovitost te stopnje je aritmetična sredina verjetnosti uspešne terapije za preostale štiri antipsihotike, ki še niso bili uporabljeni. Veje so za vsa zdravila prostorsko enake. Imamo pet enakih glavnih vej. Vejo za kvetiapin smo razvili na sliki do konca, preostale smo označili z imenom, ker gre za enake poti.

Raziskava je zasnovana z vidika plačnika, v Sloveniji je to Zavod za zdravstveno zavarovanje Republike Slovenije (ZZZS). Upoštevali smo večino neposrednih medicinskih stroškov; $v$ raziskavo smo vključili strošek psihiatrične obravnave $v$ bolnišnici, stroške zdravljenja z zdravili, ambulantne obiske pri specialistu, morebitno ponovno hospitalizacijo zaradi relapsa, stroške zamenjave zdravila in stroške obdelave in vročitve recepta. $V$ raziskavo nismo vključili stroške neželenih učinkov zdravil. $V$ ceni psihiatričnega primera $v$ bolnišnici so vključeni vsi posegi, strokovni pregledi, nega, laboratorijske preiskave, prehrana, namestitev, oskrba in zdravila za čas, ko je bolnik v bolnišnici. Posredni stroški, kot so odsotnost z dela, stroški skrbnikov in izguba produktivnosti, niso vključeni v raziskavo. Tudi neotipljivi stroški, kot je psihična prizadetost, niso vključeni $v$ raziskavo. Izvedli smo enoletno raziskavo.

\subsection{Klinični izidi atipičnih antipsihotikov}

$\mathrm{V}$ raziskavi smo uporabili dve vrsti kliničnih izidov. Prvi je odziv, ki je večji ali enak kot $30 \%$ zmanjšanja točk vprašalnika PANSS (angl. Positive and Negative Syndrome Scale) od izhodišča do končne točke. V odločitveno drevo raziskave smo vključili klinične študije, ki vsebujejo delež prekinitve zdravljenja z zdravilom v obdobju šestih tednov in enega leta. Druga vrsta uporabljenega kliničnega izida je definiran klinični izid ob koncu obdobja raziskave, popolna remisija ali relaps s hospitalizacijo.

Klinične izide atipičnih antipsihotikov smo iskali v bazi Medline/PubMed. Uporabili smo naslednjo iskalno strategijo: 'schizophrenia' AND 'risperidone' OR 'olanzapine' OR 'quetiapine' OR 'paliperidone' OR 'aripiprazole'. Iskanje smo omejili na klinične študije (angl. Clinical trials), metaanalize (angl. Meta- 
analysis) in študije na ljudeh (angl. Human). Dobili smo 2300 zadetkov. Nadaljnji izbor je potekal gleda na izključitvena in vključitvena merila. Vključitvena merila so bila: diagnoza shizofrenije, primerjava $s$ placebom, vzorec večji od 30 , odzivnost na bazno linijo (vprašalnik PANSS), uporaba odmerkov v terapevtskem območju antipsihotikov, kratkotrajne in enoletne dvojno slepe študije, interval zaupanja za relativno tveganje in peroralne farmacevtske oblike. Izključitvena merila so bila: rezistentna shizofrenija, prisotnost preostalih diagnoz, razen shizofrenije, večletne študije, intravenske in intramuskularne farmacevtske oblike, razlogi za opustitev študije pri preizkušancih, pomanjkanje intervala zaupanja pri rezultatih študij in neterapevtski odmerki zdravil. Študije, ki smo jih natančneje pregledali, smo povzeli v Tabeli 1. Učinkovitost so avtorji definirali kot razmerje tveganja (angl. relative risk) med zdravilom in placebom pri preizkušancih glede na vnaprej definiran odziv v študiji.

Tabela 1. Stopnja odziva placeba in atipičnega antipsihotika v izbranih študijah.

Table 1. Placebo and atypical antipsychotic response rates of selected comparator trials.

\begin{tabular}{|c|c|c|c|c|c|c|}
\hline $\begin{array}{l}\text { Ime } \\
\text { učinkovine } \\
\text { Drug name }\end{array}$ & $\begin{array}{l}\text { Vrsta študije } \\
\text { Study design }\end{array}$ & $\begin{array}{l}\text { Dnevni } \\
\text { odmerek } \\
\text { (mg/dan) } \\
\text { Daily Dose } \\
\text { (mg/day) }\end{array}$ & $\begin{array}{l}\text { Definicija odziva } \\
\text { Definition of } \\
\text { response }\end{array}$ & $\begin{array}{l}\text { Odziv } \\
\text { placeba na } \\
\text { določen } \\
\text { prag (\%) } \\
\text { Placebo } \\
\text { response } \\
\text { rate }(\%)\end{array}$ & $\begin{array}{l}\text { Odziv } \\
\text { atipičnega } \\
\text { antipsihotika } \\
\text { na določen } \\
\text { prag (\%) } \\
\text { Atypical } \\
\text { response rate } \\
(\%)\end{array}$ & $\begin{array}{l}\text { Viri } \\
\text { Reference(s) }\end{array}$ \\
\hline Paliperidon & $\begin{array}{l}\text { 6-tedenska, pacienti z } \\
\text { akutno shizofrenijo }\end{array}$ & $3,6,9$ in 12 & $\begin{array}{l}\text { >or=40 \% zmanjšanje } \\
\text { PANSS od izhodišča } \\
\text { do končne točke }\end{array}$ & $44,0 \%$ & $64,6 \%$ & $(14,15)$ \\
\hline Paliperidon & $\begin{array}{l}\text { 6-tedenska, pacienti z } \\
\text { akutno shizofrenijo }\end{array}$ & $3,6,9$ in 12 & $\begin{array}{l}\text { >or=30 \% zmanjšanje } \\
\text { PANSS od izhodišča } \\
\text { do končne točke }\end{array}$ & $27,4 \%$ & $50,8 \%$ & (16) \\
\hline Risperidon & $\begin{array}{l}\text { 4-tedenska študija, } \\
\text { pacienti s shizofrenijo } \\
\text { ali shizoafektivno } \\
\text { motnjo, primerjava z } \\
\text { aripiprazolom }\end{array}$ & 6 & $\begin{array}{l}\text { >or=30 \% zmanjšanje } \\
\text { PANSS od izhodišča } \\
\text { do končne točke }\end{array}$ & 23,3 & 40,0 & (16) \\
\hline Olanzapin & $\begin{array}{l}\text { 6-tedenska študija, } \\
\text { pacienti s shizofrenijo, } \\
\text { primerjava s } \\
\text { paliperidonom }\end{array}$ & 10 & $\begin{array}{l}\text { >or=30 \% zmanjšanje } \\
\text { PANSS od izhodišča } \\
\text { do končne točke }\end{array}$ & 27,4 & 50,1 & (20) \\
\hline Kvetiapin & $\begin{array}{l}\text { 6-tedenska študija, } \\
\text { pacienti s shizofrenijo }\end{array}$ & 750 & $\begin{array}{l}\text { >or=30 \% zmanjšanje } \\
\text { PANSS od izhodišča } \\
\text { do končne točke }\end{array}$ & 35,0 & 49,0 & (19) \\
\hline Aripiprazol & $\begin{array}{l}\text { 4-tedenska študija, } \\
\text { pacienti s shizofrenijo } \\
\text { ali shizoafektivno } \\
\text { motnjo, primerjava z } \\
\text { risperidonom }\end{array}$ & 20 in 30 & $\begin{array}{l}\text { >or=30 \% zmanjšanje } \\
\text { PANSS od izhodišča } \\
\text { do končne točke }\end{array}$ & 23,3 & 38,1 & (17) \\
\hline
\end{tabular}

Pri pregledu študij za paliperidon smo pridobili podatke o kliničnem odzivu na zdravljenje, izmed njih smo nato najprej pregledali šest tedensko študijo avtorjev Canusoa et al. Študija vsebuje 195 preizkušancev s paliperidonom in $75 \mathrm{~s}$ placebom, vendar je sponzorirana (14). V drugi šest tedenski dvojno slepi študiji so avtorji Canuso et al. primerjali odziv zdravljenja paliperidona, placeba in kvetiapina. Ugotovili so statistično značilno razliko med učinkovitostjo paliperidona in kvetiapina $v$ korist paliperidona po lestvici PANSS, vendar je zaradi primerjave s kvetiapinom možna neposredna primerjava učinkovitosti med kvetiapinom in paliperidonom. Študija je sponzorirana, vendar vsebuje vsa ostala vključitvena merila (15). Natančneje smo pregledali tudi študijo avtorjev Kanea et al. Študija ima definiran odziv $30 \%$ zmanjšanja točk po PANSS in ni sponzorirana. Študija je multicentrična in vključuje 628 preizkušancev (16). Za risperidon obstaja veliko študij, kjer primerjajo 
raziskovalci risperidon s placebom. Kot referenčno študijo smo izbrali štiri tedensko študijo, katere rezultati kažejo značilno izboljšanje po vprašalniku PANSS v primerjavi s placebom. Avtorji so primerjali risperidon tudi $z$ aripiprazolom. Študija je multicentrična, ni sponzorirana, odziv zdravljenja je definiran na $30 \%$ PANSS, zajema 404 preizkušance in vsebuje največ vključitvenih meril (17). Večina študij risperidona vsebuje nizko število preizkušancev, merilo odziva ni definirano po lestvici PANSS, razlogi za opustitev študije in intervali zaupanja za učinkovitost niso navedeni.

Za kvetiapin smo v bazi Medline/PubMed našli devet študij, ki so ustrezale našim merilom. Kot najbolj relevantno smo izbrali študijo avtorjev Kahna et al., iz katere je razvidno, da je enkrat dnevno jemanje kvetiapina $s$ podaljšanim sproščanjem pri akutnih shizofrenih bolnikih bolj učinkovito od placeba. Študija je primerna za primerjavo med atipičnimi antipsihotiki, ker je za klinični odziv uporabljena skala PANSS. Študija je multicentrična, ni sponzorirana, vključuje 588 preizkušancev, razlogi za opustitev študije so natančno navedeni (18). Relevantna bi bila tudi študija avtorjev Avantias et. al., kjer so avtorji za klinični odziv uporabili lestvico BPRS (angl. Brief Psychiatric Rating Scale), ustrezno zmanjšanje od izhodišča za $30 \%$. Zaradi drugega vprašalnika je rezultate te študije težje primerjati z ostalimi v Tabeli 1 (19).

Za olanzapin smo $v$ bazi našli štirinajst dvojno slepih šest tedenskih naključnih študij s placebom. Našli smo študijo, ki primerja olanzapin s paliperidonom. To je tudi edina študija, v kateri so avtorji klinični odziv definirali kot $30 \%$ odklon od izhodišča po vprašalniku PANSS, zato je najbolj relevantna za našo raziskavo. Študija je multicentrična, ni sponzorirana, vključuje 628 preizkušancev, jasno so navedeni razlogi za opustitev študije in intervali zaupanja za relativna tveganja (20). $\mathrm{Za}$ aripiprazol smo našli štiri kratke dvojno slepe študije, kjer so avtorji primerjali varnost in učinkovitost aripiprazola $v$ primerjavi s placebom. Študijo avtorjev Potkina et. al. smo izbrali kot vir za klinični odziv aripiprazola, kjer so izbrali $20 \mathrm{mg} / \mathrm{dan}$ in $30 \mathrm{mg} / \mathrm{dan}$ aripiprazola. Kot odziv placeba in aripiprazola so avtorji izračunali povprečen odziv glede na dnevna odmerka in število bolnikov. Študija je najbolj relevantna, ker so avtorji primerjali aripiprazol z risperidonom in placebom, vključili so 404 preizkušance, navedli razloge za opustitev študije, intervale zaupanja za relativna tveganja, študija pa tudi ni sponzorirana (17).

Vsi rezultati kliničnih študij v tabeli prikazujejo statistično značilno zmanjšanje točk vprašalnika PANSS v primerjavi s placebom.

Izbrane študije nismo neposredno uporabili pri izračunu stroškovne učinkovitosti posameznih antipsihotikov, ampak za končno primerjavo učinkovitosti z rezultati učinkovitosti naše raziskave. Iz izbranih študij lahko izračunamo absolutno tveganje za posamezne primere in lahko tako neposredno primerjamo učinkovitosti antipsihotikov, ki pa ni najbolj zanesljiva, saj imamo veliko študij. Zaradi pomanjkanja metaanaliz, ki bi primerjale vse navedene antipsihotike, lahko učinkovitost primerjamo prek placeba. Posebej primerne so študije, ki primerjajo dva antipsihotika med seboj (angl. head to head), saj dobimo tako neposredno relativno tveganje in se s tem izognemo morebitnim napakam pri pretvorbi prek placeba in napakam zaradi dodatne študije.

Posledično smo zgoraj opisane študije izbrali kot primerjalne našim končnim rezultatom, spodaj navedene pa za vnos podatkov $v$ odločitveno drevo, saj primerjajo več zdravil v eni študiji. Za aripiprazol in paliperidon smo podatke vzeli iz navedenih študij, saj aripiprazol in paliperidon nista vključena v multicentrično primerjalno raziskavo CATIE.

Za podatek o deležu prekinitve terapije $v$ šest tedenskem obdobju in odzivu na zdravljenje v eno letnem obdobju smo izbrali podatke študij multicentrične primerjalne raziskave CATIE in raziskave avtorjev Dossenbacha et. al. Podatki so v Tabeli $2(21,22)$. Podatek za paliperidon smo pridobili iz študije avtorjev Canusoa et. al., kjer so raziskovalci primerjali paliperidon s kvetiapinom in placebom; podatek za aripiprazol pa iz študije avtorjev Nelsona et. al, ki najbolj ustreza vključitvenim merilom $(15,23)$. CATIE raziskava je bila pogosto uporabljena v študijah stroškovne učinkovitosti, saj je multicentrična, vključuje 1493 preizkušancev, je naključna, dvojno slepa in ni sponzorirana (24). V raziskavi je zajetih več zdravil in prinaša neposredne vrednosti relativnega tveganja in verjetnost relapsa pri zdravljenju. Vsekakor bi potrebovali več prospektivnih, večjih, naključnih študij, kjer bi neposredno primerjali izbrane antipsihotike za boljšo oceno učinkovitosti.

Po neuspešnem zdravljenju s prvim antipsihotikom smo izključili ponovno uvedbo prvotnega antipsihotika. Verjetnost zamenjave za določeni antipsihotik smo predvideli glede na tržni delež na slovenskem trgu leta 2011 in posledično izračunali ustrezno verjetnost kot aritmetično sredino ostalih štirih antipsihotikov, ki še niso bili uporabljeni v terapiji (25). 
Tabela 2. Delež prekinitve (\%) zdravljenja po šestih tednih in po enem letu $(21,22,23,15)$.

Table 2. Discontinuation rates at 6 weeks and 1 year $(21,22,23,15)$.

\begin{tabular}{|l|c|c|}
\hline $\begin{array}{l}\text { Ime učinkovine } \\
\text { Drug name }\end{array}$ & $\begin{array}{l}\text { Delež prekinitve po šestih tednih (\%) } \\
\text { 6-week discontinuation rate (\%) }\end{array}$ & $\begin{array}{l}\text { Delež neodzivnih bolnikov na terapijo po enem } \\
\text { letu (\%) } \\
\text { Percentage of NonResponder in 1-year (\%) }\end{array}$ \\
\hline Paliperidon & 15,0 & 26,7 \\
\hline Risperidon & 15,0 & 31,7 \\
\hline Olanzapin & 15,0 & 25,4 \\
\hline Kvetiapin & 18,0 & 40,0 \\
\hline Aripiprazol & 14,0 & 40,0 \\
\hline
\end{tabular}

\subsection{Ekonomski izidi atipičnih antipsihotikov}

Pri raziskavi smo upoštevali povprečni dnevni odmerek atipičnega antipsihotika v vzdrževalni fazi za zdravljenje shizofrenije, ki smo ga povzeli po Povzetku o glavnih značilnosti zdravila (angl. Summary of Product Characteristics, kratica SmPC). Prek podatkov letnega prometa bolnišnic in ambulant v letu 2011 smo izračunali povprečne cene povprečnega dnevnega odmerka zdravila iz podatkov programa Pharmis ${ }^{\circledR}$ (25). Pri deležu prometa $z$ določenim antipsihotikom smo upoštevali samo atipične antipsihotike $v$ trdni peroralni farmacevtski obliki. V Tabeli 3 so zbrani podatki za leto 2011, cene so v EUR, brez DDV. V raziskavo smo vključili atipične antipsihotike, ki imajo tržni delež več kot $4,00 \%$ in so torej med petimi atipičnimi antipsihotiki, ki imajo največji tržni delež med atipičnimi antipsihotiki v letu 2011.

Tabela 3. Cene povprečnega dnevnega antipsihotičnega zdravljenja in tržni delež med atipičnimi antipsihotiki v Sloveniji v letu 2011 (25).

Table 3. The cost of antipsychotic medication as average daily dose and market share of atypical antypsihotics in Slovenia in 2011 (25).

\begin{tabular}{|l|c|c|c|}
\hline $\begin{array}{l}\text { Ime učinkovine } \\
\text { Drug name }\end{array}$ & $\begin{array}{l}\text { Tržni delež 2011 (\%) } \\
\text { Market share } \\
\text { in 2011 (\%) }\end{array}$ & $\begin{array}{l}\text { Povprečni dnevni } \\
\text { odmerek (mg) } \\
\text { Average daily dose (mg) }\end{array}$ & $\begin{array}{l}\text { Povprečna letna cena za povprečni } \\
\text { dnevni odmerek (EUR) } \\
\text { Average price for average daily dose (€) }\end{array}$ \\
\hline Olanzapin & 30,4 & 12,5 & 4,13 \\
\hline Kvetiapin & 23,7 & 375 & 2,95 \\
\hline Risperidon & 16,6 & 5 & 1,59 \\
\hline Aripiprazol & 15,4 & 15 & 5,48 \\
\hline Paliperidon & 4,65 & 6 & 6,61 \\
\hline
\end{tabular}

Cene zdravljenja psihiatričnih bolnikov smo pridobili iz podatka na internetni strani ZZZS. Cena zdravljenja psihiatričnih bolnikov je različna glede na primere (26). Imamo primer celostne psihiatrične obravnave, ki ima enotno ceno. Ta cena zajema vse storitve $v$ bolnišnici, od sprejema do odpusta iz bolnišnice. Omejena je na čas enega leta. Če je čas daljši, se zaračunata dva primera specialističnega bolnišničnega dejanskega primera. Za bolnike, ki so na neakutni obravnavi, se dodatno, poleg primera, prišteje še paliativna zdravstvena oskrba na dan. Opravka imamo tudi $s$ pacienti, katerim sodišče dodeli zdravljenje, tem pacientom se zaračunava zdravljenje po bolnišnično oskrbnem dnevu (27). V naši študiji smo upoštevali podatek celostne obravnave primera, da bi dobili čim bolj realno sliko v Sloveniji, ker je ostalih primerov bistveno manj. Posledično smo upoštevali psihiatrični primer in ne bolnišnično oskrbne dni (BOD). Cene storitev v Sloveniji se med bolnišnicami razlikujejo, zato smo uporabili povprečno ceno v Sloveniji. V študiji smo upoštevali hospitalizacijo šest tednov $v$ primeru prve uspešne terapije. Ob prvi neuspešni terapiji smo predvideli zamenjavo antipsihotika. Ob izboljšanju je sledil odpust iz bolnišnice. Pri poslabšanju je sledila rezistentna shizofrenija. Po odpustu bolnika iz bolnišnice smo upoštevali ambulantni pregled pri specialistu na tri mesece. $V$ celotni ceni zdravljenja smo upoštevali še izdajo in vročitev receptov. 
Tabela 4. Cena storitve mentalnega zdravstvenega varstva po enotah v EUR (26).

Table 4. Mental healthcare unit costs in euro (26).

\begin{tabular}{|l|c|}
\hline $\begin{array}{l}\text { Vrsta duševnega zdravstvenega varstva } \\
\text { Type of mental healthcare }\end{array}$ & $\begin{array}{l}\text { Cena storitve v EUR, brez DDV (€) } \\
\text { Unit costs service without VAT (€) }\end{array}$ \\
\hline Specialistični bolniški dejanski psihiatrični primer & 4562,4 \\
\hline BOD do vključno 48 dni & 122,1 \\
\hline BOD 48 dni ali več & 59,9 \\
\hline Zdravstvena nega in paliativna oskrba & 96,6 \\
\hline Obisk pri specialistu ambulantno psihiatrija & 29,3 \\
\hline
\end{tabular}

\section{REZULTATI}

Rezultate analize smo predstavili z diagramom stroškovne učinkovitosti enoletnega zdravljenja (Slika 2). Iz grafikona je razvidno, da so dominirane strategije aripiprazol, kvetiapin in paliperidon, ker obstajajo strategije, ki so cenejše in učinkovitejše. Najcenejše letno zdravljenje, med izbranimi strategijami atipičnih antipsihotikov je zdravljenje z risperidonom. Zdravljenje z risperidonom je manj učinkovito kot zdravljenje z olanzapinom. Iz rezultatov analize stroškovne učinkovitosti lahko sklenemo, da je strategija zdravljenja $\mathrm{s}$ kvetiapinom in aripiprazolom absolutno prevladana $\mathrm{z}$ risperidonom. Številčne vrednosti so zbrane v Tabeli 5. Iz tabele vidimo klinično učinkovitost glede na odstotek bolnikov v letni popolni remisiji. Najbolj učinkovito zdravljenje je strategija z olanzapinom, kjer je 72,3\% bolnikov v remisiji. Najmanj učinkovito je zdravljenje $s$ kvetiapinom kjer je 60,5 \% bolnikov v remisiji.

Najdražje je zdravljenje z aripiprazolom $8230 €$, najcenejše pa zdravljenje $z$ risperidonom $6812 €$. Glede na cene zdravil je najdražja zamenjava kvetiapina $s$ paliperidonom. Strategija $z$ olanzapinom ima najmanjše razmerje stroškovne učinkovitosti, $10091 €$ na preprečen relaps in je posledično najbolj stroškovno učinkovito zdravljenje bolnikov $z$ akutno shizofrenijo v Sloveniji. Strategija zdravljenja z olanzapinom ima v primerjavi $z$ risperidonom vrednost ICER $9288 € /$ preprečen relaps glede na risperidon. To pomeni, da je to dodaten strošek pri zdravljenju z olanzapinom, ki ga je potrebno plačati za večjo učinkovitost zdravljenja akutne shizofrenije $z$ olanzapinom $v$ primerjavi $z$ risperidonom.

Slika 2. Rezultati analize stroškovne učinkovitosti.

Figure 2. Outcomes of cost-effectiveness analysis.

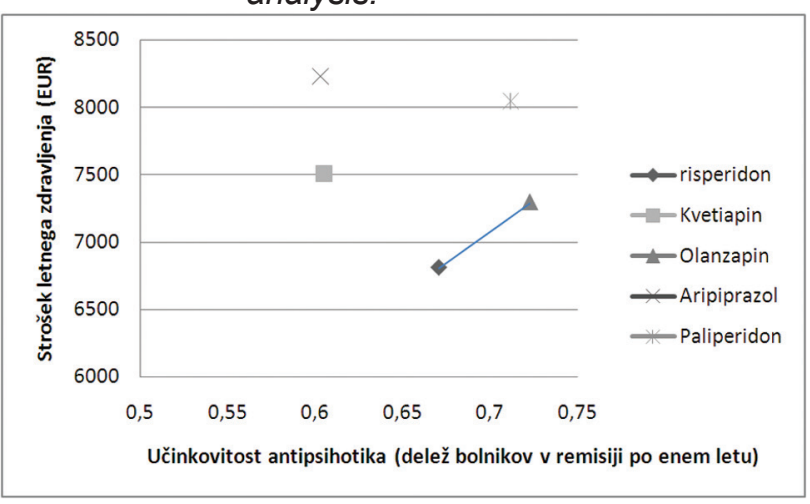


Tabela 5. Rezultati analize.

Table 5. Outcomes of analysis.

\begin{tabular}{|l|l|l|l|l|l|l|}
\hline $\begin{array}{l}\text { Strategija } \\
\text { zdravljenja } \\
\text { Tratment } \\
\text { strategy }\end{array}$ & $\begin{array}{l}\text { Stroški (€) } \\
\text { Costs }(\boldsymbol{\xi})\end{array}$ & $\begin{array}{l}\text { Prirastek } \\
\text { stroškov (€) } \\
\text { Increment of } \\
\text { costs } € \text { ) }\end{array}$ & $\begin{array}{l}\text { Učinkovitost } \\
\text { (remisija) }\end{array}$ & $\begin{array}{l}\text { Prirastek } \\
\text { učinkovitosti } \\
\text { Increment of } \\
\text { effectiveness }\end{array}$ & $\begin{array}{l}\text { ICER (€/remisija) } \\
\text { (€/remission) }\end{array}$ & $\begin{array}{l}\text { Razmerje stroški/ } \\
\text { učinkovitost } \\
\text { (€/preprečen relaps) } \\
\text { Ratio cost/effectiveness } \\
\text { (€/one prevented relapse) }\end{array}$ \\
\hline Risperidon & 6812 & 0 & 0,671 & 0 & - & 10153 \\
\hline Kvetiapin & 7509 & 214 & 0,605 & $-0,118$ & Dominirana & 12412 \\
\hline Olanzapin & 7295 & 482 & 0,723 & 0,052 & 9288 & 10091 \\
\hline Aripiprazol & 8229 & 934 & 0,603 & $-0,120$ & Dominirana & 13648 \\
\hline Paliperidon & 8044 & 749 & 0,712 & $-0,011$ & Dominirana & 11298 \\
\hline
\end{tabular}

\section{RAZPRAVA}

Pri raziskavi smo najprej izbrali iskalno metodologijo. $Z$ iskalno strategijo smo dobili veliko količino člankov. Podatke smo iskali v eni bazi. Pri pregledu člankov smo ugotovili pomanjkanje ustreznih metaanaliz, ustreznih odmerkov v študijah, velikosti vzorca študij, pomanjkanje razlogov za opustitev študij in intervalov zaupanja za relativno tveganje ter ustreznih farmacevtskih oblik. Pri ustreznih kliničnih študijah smo se osredotočili na novejše študije, $v$ katerih smo našli tudi primerjave med zdravili, ki so vključene $v$ raziskavo. Tako smo lažje primerjali neposredno učinkovitost $v$ eni študiji. Ugotovili smo pomanjkanje ustreznih študij za novejša zdravila. Izpostavili bi pomanjkanje primerjalnih študij učinkovitosti paliperidona $v$ primerjavi $z$ risperidonom in primerjalnih študij med posameznimi antipsihotiki. $Z$ izbiro navedenih izključitvenih meril smo omogočili izvedbo raziskave. Iz raziskave smo razen trdnih farmacevtskih oblik izključili ostale farmacevtske oblike. Izključili smo tudi najnovejše depo oblike antipsihotikov, ker ni bilo dovolj relevantnih podatkov. Depo obliki olanzapina in paliperidona sta bili v Sloveniji v zadnjem času tudi razvrščeni na listo zdravil (28). Za te oblike bo $v$ prihodnje potrebno opraviti več analiz stroškovne učinkovitosti. $V$ raziskavi smo se omejili na relaps po šestih tednih, dvanajstih tednih ob prvotni neuspešni terapiji in relaps tik pred enim letom. Za šest tedensko obdobje imamo veliko kliničnih študij učinkovitosti, prav tako so na voljo študije za enoletno obdobje učinkovitosti. Šest tedensko obdobje je pogosto obdobje ocenitve neuspešnosti antipsihotika $v$ klinični praksi. Uporabljena obdobja so $v$ študijah stroškovne učinkovitosti antipsihotikov pogosta (29).

Iz raziskave smo izključili vse ostale diagnoze, čeprav je komorbidnost pri shizofreniji velika (30). S tem smo si olajšali primerjavo med posameznimi strategijami. Izključili smo tudi morebitne klinično pomembne interakcije med zdravili, ki so pri antipsihotikih pogoste (31). Vključitveno merilo lestvica PANSS je osnova za primerjavo posameznih študij, zato smo z enakim kriterijem odziva lažje primerjali študije med seboj. Evidentno je pomanjkanje ustreznih relevantnih študij. Iskali smo dvojno slepe študije na ljudeh, primerjalne študije med antipsihotiki in metaanalize, ter tako zmanjšali statistične napake in povečali moč napovedovanja naših rezultatov. Izgubili smo pomembne podatke, predvsem za nove učinkovine, ki nimajo ustreznega števila omenjenih študij. Zaradi pomanjkanja enoletnih študij smo primerjali tudi rezultate šest tedenskih študij, saj smo te lahko najbolj enostavno primerjali prek istih meril. $V$ raziskavo smo pri izračunu končnih učinkovitosti zdravljenja vključili relevantno multicentrično raziskavo CATIE, ki so jo raziskovalci pogosto vključili $v$ študije stroškovne učinkovitosti $(29,33)$. Ob primerjavi učinkovitosti posameznih antipsihotikov $v$ izbranih primerjalnih kratkih študijah in uporabljenih študijah v našem odločitvenem drevesu vidimo podobnosti. Olanzapin, paliperidon in risperidon so najbolj učinkovita zdravila v naši raziskavi, prav tako pa tudi v primerjalnih študijah, ki smo jih izbrali prek iskalne metodologije. $\mathrm{V}$ obeh primerih sta aripiprazol in kvetiapin najmanj učinkoviti zdravili.

$\checkmark$ raziskavi smo za izračun inkrementnega razmerja stroškov in učinkovitosti (angl. Incremental cost effectiveness ratio, kratica ICER) uporabili spremembo 
$v$ verjetnosti remisije med strategijama. Posledično ima kvaliteta podatkov o remisiji antipsihotikov ključen pomen pri izračunu vrednosti ICER in razmerja stroškovne učinkovitosti. Odločili smo se za uporabo raziskave CATIE in navedenih študij za paliperidon in aripiprazol, saj sta najbolj ustrezali vključitvenim merilom. Iz rezultatov uporabljenih študij $v$ raziskavi in izbranih šest tedenskih študij vidimo dobro korelacijo. Najbolj učinkovito je zdravljenje z olanzapinom, paliperidonom in risperidonom, najmanj pa z aripiprazolom in kvetiapinom. Vpliv na ICER ima tudi cena letnega zdravljenja. Največji strošek je hospitalizacija, zato je učinkovito zdravljenje tudi ekonomsko ugodno. $V$ študijo smo vključili samo atipične antipsihotike $s$ tržnim deležem v Sloveniji več kot $4 \%$ med atipičnimi antipsihotiki v letu 2011 (25). Triciklični antidepresivi imajo več neželenih učinkov, njihova uporaba v zadnjih letih upada, cene so nizke, zato niso tako zanimivi za analizo stroškovne učinkovitosti.

Izbrali smo ustrezno strategijo v odločitvenem drevesu, ki je za vse učinkovine enaka. S tem smo poenostavili primerjavo med strategijami. Po dveh neuspešnih zdravljenjih je sledil končni relaps. Na tem mestu bi lahko dodali še eno stopnjo. Dodali bi klozapin, ki je učinkovit pri rezistentni shizofreniji in se uporablja kot zadnje zdravilo pri zdravljenju rezistentne shizofrenije (32). V raziskavi nismo upoštevali zdravljenja $z$ dvema antipsihotikoma hkrati, ampak samo monoterapijo. Zdravljenje z dvema antipsihotikoma hkrati ima $v$ kliničnih študijah nasprotujoče si rezultate in ni priporočljivo po smernicah za zdravljenje shizofrenije, bistveno pa poviša stroške zdravljenja in pojavnost neželenih učinkov (34). V našo raziskavo smo vključili povprečne srednje priporočene odmerke atipičnih antipsihotikov, ki so pogosto nižji kot se jih v zdravljenju dejansko uporabi. V določenih primerih so ti odmerki nižji kot odmerki v kliničnih študijah, zato je pomanjkljivost te metode neenakomernost odmerkov med študijami, prednost pa lažja obdelava podatkov. Zaradi novih podatkov (januar 2012) in kratkega obdobja raziskave $v$ raziskavo nismo vključili diskontiranja. Stroški, ki so v raziskavo vključili, so le neposredni medicinski stroški, za natančnejšo primerjavo pa bi morali vključiti še neposredne nemedicinske stroške ter posredne in neotipljive stroške.

Pri stroških smo predpostavili, da so cene hospitalizacije, ambulantnih obiskov in obdelave $z$ vročitvijo recepta enake za vse strategije. Cenovno se ločijo strategije po ceni povprečnega dnevnega odmerka atipičnega antipsihotika in ceni zdravil pri zamenjavi zdravila. Najcenejše zdravilo je risperidon, posledično je menjava za preostala zdravila pri risperidonu najdražja. Nasprotno je pri paliperidonu in olanzapinu, ki sta najdražji zdravili, njuna menjava pa najcenejša. $\checkmark$ raziskavi nismo upoštevali stroškov morebitnih neželenih učinkov antipsihotičnih zdravil. $V$ večini študij ocenjujejo, da so te vrednosti na enoletni ravni nepomembne, zato jih lahko zanemarimo (35). Iz skupnih stroškov zdravljenja vidimo, da je največji strošek hospitalizacija (več kot 50 \% stroškov celotnega zdravljenja). Strošek najcenejše strategije zdravljenja $z$ risperidonom je $82,8 \%$, najdražje $z$ aripiprazolom in $84,7 \%$ s paliperidonom. Če primerjamo samo strošek zdravila, je dnevno zdravljenje z risperidonom $24,1 \%$ zdravljenja s paliperidonom in $29,1 \% \mathrm{z}$ aripiprazolom. Posledično vidimo veliko večje razlike $v$ razmerjih stroškov dnevnega odmerka $v$ primerjavi $z$ razmerji stroškov letnega zdravljenja med posameznimi strategijami. Iz navedenega sledi, da je za večjo stroškovno učinkovitost zdravljenja potrebno upoštevati celotne stroške zdravljenja bolezni in posvetiti veliko pozornosti večji optimizaciji zdravljenja z zdravili in preprečitvi relapsa. Premalo je zgolj nižati stroške zdravil, ki so v celoletnem strošku zdravljenja bolnikov z akutno shizofrenijo relativno nizki. Pomanjkljivost naših navedenih stroškov je predvsem pomanjkanje ustreznih primerjalnih kliničnih študij učinkovitosti med izbranimi antipsihotiki, predvsem enoletnih. Posledično smo morali učinkovitost med antipsihotiki preračunati glede na razmerje antipsihotik/placebo za posamezni antipsihotik. $\mathrm{V}$ nekaterih študijah izberejo skupino strokovnjakov, ki na osnovi obiskov pri specialistu ocenijo te vrednosti, vendar je to največkrat vzrok velikih napak (36). V naši raziskavi smo predpostavili, da se relaps zgodi ali po šestih tednih, dvanajstih tednih ali tik pred enim letom.

$\checkmark$ raziskavo nismo vključili vpliva neželenih učinkov atipičnih antipsihotikov. Risperidon in paliperidon imata višjo verjetnost pojava ekstrapiramidnih simptomov (EPS) kot aripiprazol, kvetiapin in olanzapin. Med izbranimi antipsihotiki povzroča olanzapin povprečno največ težav s povečanjem telesne teže. Kvetiapin ima največji vpliv na podaljšanje intervala QT-c, paliperidon in risperidon pa na povišanje vrednosti prolaktina in na hipotenzijo. Posledica navedenih neželenih učinkov je lahko menjava terapije in uporaba drugega antipsihotika, vendar neželeni učinki nimajo bistvenega vpliva na rezultate analiz stroškovne učinkovitosti (35). Naša raziskava lahko pripomore $k$ izboljšanju klinične prakse predpisovanja atipičnih antipsihotikov. Stroškovna učinkovitost, izhajajoča iz tržnih deležev v letu 2011, ne sovpada z rezultati naše raziskave. Velik tržni delež imata aripiprazol in kvetiapin, ki nista najbolj učinkovita. Kljub najnižji ceni zdravljenja z risperidonom je njegov tržni delež nizek. Po drugi strani imamo veliko porabo aripiprazola in kvetiapina, ki kažeta visoke vrednosti razmerja stroškovne učinkovitosti, obe 
strategiji sta dominirani z risperidonom. Predpisovanje paliperidona je med naštetimi atipičnimi antipsihotiki najnižje, čeprav je paliperidon bolj učinkovit kot aripiprazol in kvetiapin. Odstopanja lahko najdemo tudi v predpisovanju brez indikacije (angl. Off-label), kar povečuje delež porabe določenega antipsihotika, predvsem kvetiapina in olanzapina. Posledično je razumljiv tudi njun velik delež porabe v letu 2011. Eden izmed razlogov za drugačne vrednosti tržnega deleža in rezultatov naše analize je lahko tudi kombiniranje dveh ali več antipsihotikov hkrati, čeprav smernice za zdravljenje shizofrenije ne priporočajo kombinacij antipsihotikov in uporabo antipsihotikov brez indikacije (34). Iz rezultatov naše raziskave lahko zaključimo, da bi za zmanjšanje stroškov zdravljenja in povečanje učinkovitosti lahko predpisovali zlasti več risperidona, olanzapina in tudi paliperidona, manj pa aripiprazola in kvetiapina. Paliperidon ima najdražji povprečni dnevni odmerek, kar je lahko predvsem za bolnišnice v Sloveniji negativno, saj nosijo celotno stroškovno breme zdravljenja v bolnišnici. Kljub učinkovitosti paliperidona, ki je večja kot pri aripiprazolu, ima aripiprazol v Sloveniji veliko večji tržni delež. Eden izmed razlogov za tako stanje je tudi majhen vpliv kliničnih farmacevtov in farmakoekonomike v slovenskih bolnišnicah. Večji vpliv bi omogočil boljše informiranje in posledično zmanjšanje stroškov ter povečanje učinkovitosti zdravljenja bolnikov $\mathrm{s}$ shizofrenijo v Sloveniji.

Glede na širok spekter neželenih učinkov atipičnih antipsihotikov je terapevtsko pomembno, da obdržimo širok spekter teh zdravil kot možnost predpisovanja, vendar je $v$ večini primerov za doseganje boljših kliničnih in ekonomskih izidov potrebno upoštevati študije stroškovne učinkovitosti. Aripiprazol ima prednosti pred risperidonom, predvsem ima manj neželenih učinkov, vpliv na povišanje telesne teže je podoben, manjša je pojavnost hiperprolaktinemij, manjše je število dnevnih odmerjanj in manjša je verjetnost določenih klinično pomembnih interakcij (17). Za učinkovitejše in cenejše zdravljenje bi bilo smiselno večje predpisovanje risperidona (namesto aripiprazola). Predpisovanje aripiprazola je potrebno $v$ primerih, ko so zaželene prednosti aripiprazola. Glede na širšo indikacijo in večjo učinkovitost risperidona $v$ primerjavi $z$ aripiprazolom, lahko $v$ prihodnje pričakujemo večje predpisovanje risperidona. $\mathrm{K}$ temu lahko pripomore predstavitev neodvisnih raziskav stroškovne učinkovitosti zdravnikom in večje sodelovanje zdravstvenih delavcev pri zdravljenju in osveščanju bolnikov o njihovi terapiji. V Sloveniiji so bile v letu 2011 na listo zdravil razvrščena nove generične oblike olanzapina, $v$ prihodnosti lahko pričakujemo še dodatno znižanje cene tega zdravila, kar je dodaten razlog za večje predpisovanje olanzapina v primerjavi z aripiprazolom. Nove analize stroškovne učinkovitosti s podatki za leto 2012 bodo najverjetneje izpostavile olanzapin kot stroškovno najbolj učinkovito zdravilo za zdravljenje akutne shizofrenije (28).

Za zdaj v Sloveniji še ni omejitve predpisovanja atipičnih antipsihotikov pri indikaciji akutne shizofrenije (28). Glede na rezultate naše raziskave in drugih raziskav iz tega področja (33) je le še vprašanje časa, kako dolgo bo plačnik zdravstvenih storitev pripravljen plačevati dodatne prirastke učinkovitosti olanzapina v primerjavi z risperidonom in velik delež manj učinkovitih dražjih antipsihotikov ter njihovih kombinacij. Na skoraj vseh področjih zdravljenja imajo v Sloveniji zdravila omejitve predpisovanja, pri antipsihotikih tega sistema še nimamo. V zadnjem času prihajajo na tržišče tudi številni novi antipsihotiki v depo oblikah in smiselno bi bilo uvesti omejitve predpisovanja za določena zdravila tudi iz tega področja, preučiti njihovo stroškovno učinkovitost, za predstavitev zdravil zdravnikom pa uporabiti nesponzorirane študije. Ker trenutni sistem omogoča stroškovno neučinkovito predpisovanje zdravil, bi lahko prihranek z bolj smotrnim predpisovanjem izkoristili za učinkovitejše zdravljenje. Omejiti bi bilo potrebno predpisovanje antipsihotikov izven indikacije v skladu s Povzetkom o glavnih značilnosti zdravila, omejiti indikacijo, kot je primer antidepresivov na listi zdravil. $V$ slovenskem okolju smo zasledili samo eno raziskavo stroškovne učinkovitosti za antipsihotike. Raziskava je bila objavljena v letu 2007, njeni avtorji so Obradović et al. Raziskovali so stroškovno učinkovitost antipsihotikov pri zdravljenju kronične shizofrenije. Za razliko od naše raziskave so raziskovali ambulantne bolnike s kronično shizofrenijo, odločitveno drevo ni vključevalo zamenjave antipsihotika ob prvotni neuspešni terapiji, raziskava ni zajela najnovejšega atipičnega antipsihotika paliperidona (33). Risperidon in olanzapin sta se izkazala za najbolj stroškovno učinkoviti zdravili. To smo z novimi podatki iz leta 2011 ugotovili tudi mi. Posledično lahko obe raziskavi na tem področju pripomoreta $\mathrm{k}$ boljši uporabi stroškovne učinkovitosti v klinični praksi v Sloveniji.

\section{ZAKLJUČEK}

Med izbranimi atipičnimi antipsihotiki je najbolj stroškovno učinkovito zdravljenje akutne shizofrenije zdravljenje z olanzapinom in risperidonom. Rezultati naše raziskave lahko pripomorejo $\mathrm{k}$ izboljšanju zdravljenja bolnikov s shizofrenijo in $\mathrm{k}$ optimizaciji kliničnih in ekonomskih izidov zdravljenja. Nadaljnje študije učinkovitosti in metaanalize atipičnih antipsihotikov so potrebne za natančnejše podatke o učinkovitosti 
atipičnih antipsihotikov. Smiselno je razmisliti o omejitvah predpisovanja nekaterih antipsihotikov, glede na indikacijo, linijo in podvojitev antipsihotičnega zdravljenja ter neželene učinke. Tako bi lahko prihranek denarja namenili za povečanje učinkovitosti zdravljenja bolnikov. Pri zdravljenju bolnikov s shizofrenijo je za optimizacijo kliničnih in ekonomskih izidov potrebno sodelovanje celotnega zdravstvenega tima in večja vključitev rezultatov analiz stroškovne učinkovitosti $\checkmark$ proces zdravljenja. Izvedena raziskava in druge raziskave na tem področju zaradi vedno večjega pomanjkanja sredstev $v$ zdravstvu postajajo vodilno orodje pri optimizaciji kliničnih in ekonomskih izidov $v$ zdravstvu v razvitih državah.

\section{Literatura}

1. American Psychiatric Association. Diagnostic and statistical manual of mental disorders (4nd ed.), text revision (DSM-IV-TR). Washington DC: American Psychiatric Association, 2000.

2. Murray CJL, Lopez AD. The global burden of disease. Cambridge: Harvard University Press, 1996.

3. Kendler KS, Gallagher TJ, Abelson JM, Kessler RC. Lifetime prevalence, demographic risk factors, and diagnostic validity of nonaffective psychosis as assessed in a US community sample: The National Comorbidity Survey. Arch Gen Psychiatry 1996; 53: 1022-1031.

4. Goldner EM, Hsu L, Waraich P, Somers JM. Prevalence and incidence studies of schizophrenic disorders: a systematic review of the literature. Can J Psychiatry 2002; 47: 833-843.

5. Marder SR, Essock SM, Miller AL, Buchanan RW, Casey DE, Davis $\mathrm{JM}$ et al. Physical health monitoring of patients with schizophrenia. Am J Psychiatry 2004; 161: 1334-1349.

6. Picchioni MM, Murray RM. Schizophrenia. BMJ 2007; 335: 91-95.

7. Dixon LB, Lehman AF, Levine J. Conventional antipsychotic medications for schizophrenia. Schizophr Bull 1995; 21: 567-577.

8. Leucht S, Corves C, Arbter D, Engel RR, Li C, Davis JM. Second-generation versus first-generation antipsychotic drugs for schizophrenia: a meta-analysis. Lancet 2009; 373: 31-41.

9. Kapur S, Zipursky R, Jones C, Remington G, Houle S. Relationship between dopamine $\mathrm{D}(2)$ occupancy, clinical response, and side effects: a double-blind PET study of firstepisode schizophrenia. Am J Psychiatry 2000; 157: 514-520.

10. Buchanan RW, Kreyenbuhl J, Kelly DL, Noel JM, Boggs DL, Fischer BA, Himelhoch S, Fang B, Peterson E, Aquino PR, Keller W. Schizophrenia Patient Outcomes Research Team (PORT): the 2009 schizophrenia PORT psychopharmacological treatment recommendations and summary statements. Schizophr Bull 2010; 36: 71-93.

11. Inštitut za varovanje zdravja Republike Slovenije. Ambulantno predpisovanje zdravil v Sloveniji po ATC Klasifikaciji v letu 2009. Pridobljeno 28.1.2012 s spletne strani: http://www.ivz.si.

12. IMS health. Pridobljeno 30.1.2012 s spletne strani: http://www. IMShealth.com.

13. Weiden PJ, Olfson M. Cost of relapse in schizophrenia. Schizophr Bull 2004; 21: 419-429.

14. Canuso CM, Dirks B, Carothers J, Kosik-Gonzalez C, Bossie CA, Zhu Y, Damaraju CV, Kalali AH, Mahmoud R. Randomized, double-blind, placebo-controlled study of paliperidoneextended-release and quetiapine in inpatients with recently exacerbated schizophrenia. Am J Psychiatry 2009; 166: 691-701.
15. Canuso CM, Bossie CA, Turkoz I, Alphs L. Paliperidone extendedrelease for schizophrenia: effects on symptoms and functioning in acutely ill patients with negative symptoms. Schizophr Res 2009; 113: 56-64.

16. Kane J, Canas F, Kramer M, Ford L, Gassmann-Mayer C, Lim $P$, Eerdekens M. Treatment of schizophrenia with paliperidone extended-release tablets: a 6-week placebo-controlled trial. Schizophr Res 2007; 90:147-161.

17. Potkin SG, Saha AR, Kujawa MJ, Carson WH, Ali M, Stock E, Stringfellow J, Ingenito GG, Marder SR. Aripiprazole, an antipsychotic with a novel mechanism of action, and risperidone vs. placebo in patients with schizophrenia and schizoaffective disorder. Arch Gen Psychiatry 2003; 60: 681-690.

18. Kahn RS, Schulz SC, Palazov VD, Reyes EB, Brecher M, Svensson O, Andersson HM, Meulien D. Efficacy and tolerability of once-daily extended release quetiapinefumarate in acute schizophrenia: a randomized, double-blind, placebocontrolled study. J Clin Psychiatry 2007; 68: 832-842.

19. Arvanitis LA, Miller BG. Multiple fixed doses of "Seroquel“ (quetiapine) in patients with acute exacerbation of schizophrenia:a comparison with haloperidol and placebo. Biol Psychiatry 1997; 42: 233-246.

20. Kane J, Canas F, Kramer M, Ford L, Gassmann-Mayer C, Lim P, Eerdekens M. Treatment of schizophrenia with paliperidoneextended-release tablets: a 6-week placebocontrolled trial. Schizophr Res 2007; 90: 147-161.

21. Lieberman JA, Stroup TS, McEvoy JP, Swartz MS, Rosenheck RA, Perkins DO, Keefe RS, Davis SM, Davis CE, Lebowitz BD, Severe J, HsiaoJK. Clinical Antipsychotic Trials of Intervention Effectiveness (CATIE) investigators: effectiveness of antipsychotic drugs in patientswith chronic schizophrenia. N Engl J Med 2005; 353: 1209-1223.

22. Dossenbach M, Arango-Davila C, Silva Ibarra H, Landa E, Aguilar J,Caro O, Leadbetter J, Assuncao S. Response and relapse inpatients with schizophrenia treated with olanzapine, risperidone,quetiapine, or haloperidol: 12-month follow-up of the Intercontinental Schizophrenia Outpatient Health Outcomes (ICSOHO) study. J Clin Psychiatry 2005; 66: 1021-1030.

23. Mullins CD, Obeidat NA, Cuffel BJ, Naradzay J, Loebel AD. Risk of discontinuation of atypical antipsychotic agents in the treatment of schizophrenia. Schizophr Res 2008; 98: 8-15.

24. Lieberman JA, Stroup TS, McEvoy JP et al.; Clinical Antipsychotic Trials of Intervention Effectiveness (CATIE) Investigators. Effectiveness of antipsychotic drugs in patients with chronic schizophrenia. N Engl J Med 2005; 353: 1209-1023.

25. IMS health. Pridobljeno 30.1.2012 s spletne strani: http://www. IMShealth.com.

26. Zavod za zdravstveno zavarovanje Slovenije. Cene storitev v zdravstvu od 1.1. 2012 dalje. Pridobljeno 25.1.2012 s spletne strani: http://www.zzzs.si/zzzs/pao/izvajalci.nsf/o/0C38E1F23D 89C18FC125796F00173041.

27. Zakonodaja Republike Slovenije. Zakon o duševnem zdravju Republike Slovenije. Pridobljeno 20.1.2012 s spletne strani: http:// zakonodaja.gov.si/rpsi/r07/predpis_ZAKO2157.html.

28. Zavod za zdravstveno zavarovanje Republike Slovenije. Recept glasilo, zadnja verzija. Pridobljeno 20. 1. 2012 s spletne strani: http://www.zzzs.si/ZZZS/info/egradiva.nsf/0/2e6416e75fe33f0 5c125796c00492304/\$FILE/Bilten\%20Recept_\%C5\%A1t\%20 1_20.12.2011.pdf

29. Geitona M, Kousoulakou H, Ollandezos M, Athanasakis K, Papanicolaou S, Kyriopoulos I. Costs and effects of paliperidone extended release compared with alternative oral antipsychotic agents in patients with schizophrenia in Greece: a cost effectiveness study. Annals of General Psychiatry 2008; 7: 16. 
30. Hausmann A, Fleischhacker WW. Differential diagnosis of depressed mood in patients with schizophrenia: a diagnostic algorithm based on a review. Acta Psychiatr Scand 2002; 106: 83-96.

31. Premuš A, Mrhar A. Interakcije med zdravili pri bolnikih na kirurškem oddelku Splošne bolnišnice Murska Sobota. Zdrav Var 2010; 49: 189-201.

32. Lewis SW, Barnes TR, Davies L, Murray RM, Dunn G, Hayhurst $\mathrm{KP}$. Randomized controlled trial of effect of prescription of clozapine versus other second-generation antipsychotic drugs in resistant schizophrenia. Schizophr Bull 2006; 32: 715-723.

33. Obradović M, Mrhar A, Kos M. Cost-effectiveness of antipsychotics for outpatients with chronic schizophrenia. Int J Clin Pract 2007; 6: 1979-1988.
34. Young W. The therapeutic window for methylprednisolone treatment of acute spinal cord injury: implications for cell injury mechanisms. Res Publ Assoc Res Nerv Ment Dis 1993; 71: 191-206.

35. Vera-Llonch M, Delea TE, Richardson E, Rupnow M, Grogg A, Oster G. Outcomes and costs of risperidone versus olanzapine in patients with chronic schizophrenia or schizoaffective disorders: a Markov model. Value Health 2004; 7: 569-584.

36. Boscoe A, Paramore C, Verbalis JG. Cost of illness of hyponatremia in the United States. Cost Eff Resour Alloc 2006; 4: 10. 